Competing internationally: on the importance of R\&D for export activity

Dirk Czarnitzki and Annelies Wastyn

DEPARTMENT OF MANAGERIAL ECONOMICS, STRATEGY AND INNOVATION (MSI) 


\section{Non-technical Summary}

Export is an important factor for growth and welfare for small, open economies. Since $R \& D$ and innovation are also key factors of growth for an industrialized economy, it is interesting to analyze the relationship between $R \& D$ and export for Belgium as one example of a small, open and industrialized economy. Because of possible endogeneity of $R \& D$, we instrument $R \& D$ with information on subsidized $\mathrm{R} \& \mathrm{D}$ projects. Consequently, it can be indirectly identified whether R\&D subsidies may serve as policy tool for stimulating exports. Due to the exceptionally high openness of Belgium, and the consequential high presence of multinational enterprises (MNEs), we consider two subsamples of firms, purely domestic firms and MNEs. Differences in the relationship between $\mathrm{R} \& \mathrm{D}$ and exports may occur between domestic firms and MNEs due to intra-group transfers and possible centralization of R\&D activity in MNEs in a certain geographical area.

For the analysis, we use data from the Flemish Community Innovation Survey (CIS) 2005 and 2007. Results indicate that there is a positive effect of R\&D on exports for the full sample as well as for both subsamples. Due to possible endogeneity of R\&D, we instrument $R \& D$ with data on the lagged number of subsidized $R \& D$ projects and the lagged average size of the subsidized $R \& D$ projects. Results of this analysis indicate that $R \& D$ subsidies increase $R \& D$. This is reassuring for policy makers: first, subsidies lead to more $R \& D$ in the economy and, second, $R \& D$ increases the international sales of firms. As this is also the case for MNEs, the concern that R\&D subsidies may lead to more $R \& D$ in the economy, but in case of MNEs to no further benefits as production may take place elsewhere, is reduced. However, there is some evidence that the export stimulus resulting from $\mathrm{R} \& \mathrm{D}$ is smaller for MNEs than for domestic companies. 


\title{
Competing internationally: on the importance of R\&D for export activity ${ }^{1}$
}

\author{
Dirk Czarnitzki $^{\text {a,b,c }}$ and Annelies Wastyn ${ }^{\text {a,b,c }}$ \\ a) K.U.Leuven, Dept. of Managerial Economics, Strategy and Innovation, Belgium \\ b) Centre for R\&D Monitoring (ECOOM) at K.U.Leuven \\ c) Centre for European Economics Research (ZEW), Mannheim, Germany
}

September 2010

\begin{abstract}
Export is an important factor to improve growth and welfare especially for industrialized small, open economies such as Belgium. Policy may be interested in key variables that can influence export. This paper finds evidence for the importance of R\&D for export activities using Belgian firm-level data. To control for reverse causality, $R \& D$ subsidy variables are used to instrument $R \& D$. The results show that $\mathrm{R} \& \mathrm{D}$ policies may indirectly help to increase the export performance of the economy. Due to the exceptionally high openness of Belgium, two subsamples of firms are considered, domestic firms and multinational firms. We observe positive effects of $R \& D$ on export for both domestic and MNEs. Once we instrument $R \& D$ because of its potential endogeneity, however, it turns out that the effect of $R \& D$ on exports is larger for domestic firms than for multinational companies.
\end{abstract}

Keywords: Export, R\&D, Multinational enterprises, Innovation Policy JEL-Classification: F23, O33, O38

Annelies Wastyn

K.U.Leuven

Dept. of Managerial Economics, Strategy and Innovation

Naamsestraat 69

3000 Leuven

Belgium

Phone: + 3216326651

Fax: +32 16326732

E-Mail: annelies.wastyn@econ.kuleuven.be
Dirk Czarnitzki

K.U.Leuven

Dept. of Managerial Economics, Strategy and Innovation

Naamsestraat 69

3000 Leuven

Belgium

Phone: + 3216326906

Fax: +32 16326732

E-Mail: dirk.czarnitzki@econ.kuleuven.be

\footnotetext{
${ }^{1}$ We thank Katrin Hussinger and participants of following conferences and workshops for helpful comments: "ZEW PhD Workshop" in Mannheim, Germany; "Düsseldorf-Leuven-Mannheim Seminar on Competition and Innovation" in Düsseldorf, Germany, "Competition and Innovation Summer School 2010" in Turunç, Turkey, and "European Association for Research in Industrial Economics" Conference in Istanbul, Turkey. Financial support from IWT Flanders is gratefully acknowledged.
} 


\section{Introduction}

In a global world, exports are obviously one channel for increasing a nation's growth and long-term wealth. This is especially true for industrialized small, open economies. For policy makers, it may sound attractive to foster exports compared to other options of internationalization, such as foreign direct investment or licensing. Although potential profits of foreign direct investment and licensing would flow back to the home country as they do with exports, export activity has the feature that employment would be maintained or increased in the home country. Even if foreign direct investment would exhibit higher expected profits in certain industries, keeping employment in the home country is certainly attractive for policy makers.

What is a key variable that policy can use to influence long-term export success, however? The literature usually analyses the relationship between exports and productivity of a firm (see e.g. surveys by Wagner, 2007). In this paper, we take a slightly different perspective. $R \& D$ and innovation are typically seen as a major drivers of productivity growth (see e.g. Griliches, 1994; Hall and Mairesse, 1995) and thus also for exports of industrialized countries (Cassiman and Golovko, 2007, 2010; Cassiman et al., 2010). Whereas the literature on exports and productivity is vast, the relationship between $R \& D$ and exports received less attention in the field (see e.g. Hirsch and Bijaoui, 1985; Ebling and Janz, 1999; Arnold and Hussinger, 2005). We are interested in potential effects of policy and therefore study whether exports are stimulated by $R \& D$. As there is a reverse causality concern that $R \& D$ may be triggered by export experience of the firms (see e.g. Ebling and Janz, 1999; Lachenmaier and Wössmann, 2006), we will use instrumental variable regressions. 
These regressions in turn allow using $R \& D$ subsidy variables as instruments which will directly identify whether R\&D subsidies can serve as policy tool for stimulating exports.

We study the relationship between R\&D activity and export of firms using data from Belgium. This country can be seen as a representative for a case study of a small, open European economy. For instance, Belgian's GDP amounted to 345 billion EUR in 2008. The total volume of exports amounted to 321 billion EUR. The growing importance of exports in an ever more globalized world is striking for Belgium: nominal GDP growth between 2001 and 2008 is about 33\%, but the growth of exports amounts to $46 \%$. (All figures mentioned here were obtained from official Eurostat statistics). Belgium's high degree of openness can also be seen in both the inward and outward stocks of FDI. The FDI stocks as a percentage of GDP amounted to 133 (122) inward (outward). The inward (outward) FDI stocks of other European countries are much lower: Austria 34 (37), Finland 32 (42), Denmark 44 (55), Ireland 62 (63), Sweden 53 (67) (Source: UNCTAD, 2009).

In terms of Gross Expenditure on R\&D (GERD), Belgium ranges at about the EU27 average with a GERD to GDP ratio of about $1.9 \%$ in 2007. However, Belgium is lagging behind other small European countries in terms of R\&D. Sweden's R\&D intensity reaches 3.9\%, Finland's 3.5\% and both Denmark's and Austria's about 2.4\% (Source for all R\&D data: OECD Main Science and Technology Indicators). Thus, there is potential for policy to increase $R \& D$, and in turn possibly exports.

Because of the exceptionally high openness of Belgium, and the consequential high presence of multinational enterprises (MNEs), we consider two subsamples of firms. We compare the purely domestic firms with the MNEs, that is, firms being 
either a Belgian parent company or a Belgian subsidiary of a foreign parent company. To the best of our knowledge, this is the first study on the relationship between R\&D and export investigating the scope for innovation policy and distinguishing between domestic firms and MNEs.

We find that $R \& D$ subsidies indeed foster $R \& D$ efforts in the firm. In the full sample as well as in both subsamples there is a positive effect of $R \& D$ on export performance.

The remainder of the paper proceeds as follows: the second section discusses existing literature on export and R\&D in more detail, the third section introduces the data and variables used. The empirical analysis is presented in section four, and the final section concludes.

\section{The importance of $R \& D$ for export}

2.1 Studies on the relationship between export and innovation or R\&D

International trade theories emphasize the importance of $R \& D$ for export. The product life cycle theory of international trade (Vernon, 1966; Krugman, 1979; Dollar, 1986) indicates that innovation makes it possible to create a competitive advantage necessary for competing on international markets. Endogenous growth models treat innovation as endogenous (see Grossman and Helpman, 1989; Young, 1991). These models indicate that the effect might be two-way. Innovation may be necessary for dealing with increased competition after entry into foreign markets. However, this effect can also be reversed so that entering a foreign market and accessing technological expertise increases the probability of 'learning by exporting' which may eventually lead to innovation. 
At the firm level, several authors have also analyzed the relationship between export and innovation or R\&D. Some authors focus on innovation as an output measure of innovation effort, typically measured by dummy variables indicating the implementation of a new process, the introduction of a new product, or a single variable measuring any type of innovation. Wakelin (1998), Roper and Love (2002) and Bleaney and Wakelin (2002) find different determinants of export for innovators and non-innovators for the UK (Wakelin, 1998; Roper and Love, 2002 and Bleaney and Wakelin, 2002) and Germany (Roper and Love, 2002). Belderbos et al. (2009) find for Belgium that product innovation is important to improve exports.

Other authors focus on R\&D, as input measure of innovation effort. Hirsch and Bijaou (1985), Ito and Pucik (1993), Barrios et al. (2003) and Kirbach and Schmiedeberg (2008) find a positive effects of R\&D intensity on export performance as measured by either export probability, export sales volume or export growth for respectively Israel, Japan, Spain and Germany. In contrast, Schlegelmilch and Crook (1988) restricted their analysis to a subsample of British exporting firms only, and could not confirm an effect of R\&D on export intensity.

All the studies above have in common that they do not account for a potential reverse causality between export and innovation or R\&D. Some authors are using lags of R\&D and innovation. However, the validity of this approach may be questioned, as innovation and R\&D may be highly persistent over time (see e.g. Peters, 2009).

Therefore, some scholars explicitly account for the potential endogeneity of R\&D. Becker and Egger (2009) study the effect of product and process innovation on export for German firms, and interpret both innovation measures as a treatment. They apply a heterogeneous treatment effects model suggested by Gerfin and Lechner (2002) 
which is implemented using econometric matching techniques. Results again confirm the importance of product innovation for the propensity to export. This effect gets larger if product innovation is combined with process innovation. Process innovation alone, on the other hand, does not have a positive impact on the propensity to export.

Other studies account for the potential endogeneity of R\&D by estimating either an interdependent system of equations or by using instrumental variable (IV) approaches. Lachenmaier and Wössmann (2006) as well as Van Beveren and Vandenbussche (2010) investigate the effect of innovation, or $R \& D$ respectively, on export using IV regressions. Their results also confirm a significant positive effect of innovation on exports for respectively Germany and Belgium. Ebling and Janz (1999) estimate a system of interdependent equations for export and innovation, and find evidence that in Germany there is a positive effect of innovation activities on export. No evidence is found for the influence of export on innovation activities. Girma et al. (2008) look at the two-way effect of R\&D and export for both British and Irish firms by using interdependent equations. Significant results are found for the effect of R\&D on export and for the reverse learning-by-exporting effect for Irish firms but not for British firms. For foreign firms located in Ireland, no effect was observed. This study indicates a difference in effect between foreign and domestic firms which we will discuss more into detail in the next section.

\subsection{Export of multinational enterprises}

Research concerning the importance of the internationalization of firms is mainly concentrated on the effect on general firm performance. Performance differences are often attributed to the foreign ownership aspect of the affiliates. The theory of the multinational firm suggests, however, that it is the multinational dimension that 
induces performance gaps, but not the fact of being foreign-owned (see e.g. Bellak, 2004, for a survey). For example, De Backer and Sleuwaegen (2003) find a significantly higher productivity in Belgium for foreign-owned firms compared to domestic-owned firms. Doms and Jensen (1998) as well as Criscuolo and Martin (2009) make a distinction between domestic firms, foreign-owned MNEs and domestic-owned MNEs, using respectively data from the United States and from Great Britain. They indicate that the distinction between foreign-owned firms and domestic-owned firms is not as important as assumed. It is mainly the multinational dimension of a firm, whether foreign-owned or domestic-owned, that makes the distinction.

With respect to innovation differences, Frenz et al. (2005) show that for UK financial services it is the multinational aspect that is a more significant characteristic than the foreign ownership itself. In this line, Castellani and Zanfei (2007) find for Italy that productivity as well as innovation behavior significantly differs between MNEs and domestic firms.

When it comes to the effect of multi-nationality and innovation on export, empirical studies are scarce. Ebling and Janz (1999) only include a multinational indicator along with innovation measures in their export equation for Germany. No significant results of the multinational indicator are found. Girma et al. (2008) extend this approach and look for an answer on how being a domestic versus foreign firm changes the effect of $R \& D$ on export intensity, and vice versa. For this study, data from Ireland and Great-Britain are used. The two-way effect only appears to be present for domestic Irish firms. One possible explanation for no effect in GreatBritain is the different structure of the economy. Great-Britain is a large economy 
while Ireland is representative for a small open economy. Additionally, technology for MNEs is often sourced from abroad, and therefore Girma et al. (2008) did not expect to find an effect of export on R\&D for foreign firms in Ireland or GreatBritain.

\subsection{The contribution of our study to the literature}

Our main goal is analyzing the potential of innovation policy for stimulating exports indirectly through $\mathrm{R} \& \mathrm{D}$ spending in the business sector. To the best of our knowledge, this has not been considered in detail in the existing literature. In order to control for the possible endogeneity of $R \& D$, we instrument $R \& D$ with data on subsidized R\&D projects, more specifically the number of subsidized projects and the average size of subsidized projects. When constructing the variables, we only account for subsidized $R \& D$ projects that were completed before the $R \& D$ variable is observed in our sample. The direct effect between R\&D subsidies and R\&D has been frequently discussed in the evaluation literature (see e.g. David et al., 2000, Cerulli, 2010 for surveys, or Almus and Czarnitzki, 2003, Czarnitzki et al., 2007, Hussinger, 2008, for other examples). Therefore, subsidies appear to be good candidates for instrumental variables in our study on first sight.

Additionally, we investigate the effect of multi-nationality. The vast literature on the effect of multi-nationality on firm performance indicates that this is an interesting aspect to explore. Due to the high openness of Belgium, this becomes even more relevant. Consequently, we combine our study on the relationship between export performance and R\&D with an analysis of MNE behavior by splitting the sample into domestic companies and MNEs. Following the theory of the multinational firm, the latter group consists of firms that are either subsidiaries of foreign parents or 
headquarters of Belgian MNEs. As we already indicated, we prefer to use a distinction between domestic firms and MNEs over the distinction between domestic firms and foreign firms (e.g. Girma, 2008). With the MNE distinction we cover all firms which have international linkages, which might be the cause of concentrated R\&D or intra-group trade. ${ }^{2}$

For domestic firms, we expect that $R \& D$ will positively influence export intensity. On the one hand, R\&D can create new products which are attractive for foreigners, creating export opportunities for the firm. On the other hand, R\&D can generate process innovations, that is, because of lower marginal cost of production, goods may become more competitive on international markets and thus exports increase. Since Belgium is a small economy, foreign markets can offer additional sales opportunity which can be utilized via exports. Therefore we expect that $R \& D$ will have a positive effect on export.

For MNEs, however, it is less clear if such an effect can be identified. MNEs will have a higher propensity to export anyway, as many of their products may represent international intra-group transfers which may not depend on R\&D success of the firm.

Additionally, if MNEs increase their R\&D, this may not lead to the same increase in export as for domestic firms. On the one hand it is possible that the effect is larger.

2 Note that it would be certainly interesting to analyse Belgian headquarters and Belgian subsidiaries separately. Due to a relatively small sample size, however, we cannot do so. In addition to the results reported in the remainder of the paper, we have also considered only the subsample of Belgian subsidiaries of foreign firms instead of the MNE definition described above, and the results are robust to that change in sample definition. 
It is generally expected that MNEs source their R\&D from other parts of the MNE located abroad (Girma, 2008). Ireland is, just as Belgium, often labeled as a small open economy. Cassidy et al. (2005) indicate a possible peripheral role of R\&D expenditures for foreign firms operating in Ireland. Ireland is used as an export platform, with the main R\&D activity located in another part of the MNE. This results in low $R \& D$ intensity relative to export. On the other hand, it is possible that the effect is smaller. This can happen if R\&D centers of MNEs are not located abroad. Knowledge and innovations stemming from this R\&D are then distributed over all the production units of the MNEs across countries. Therefore it might be harder to detect an effect of the R\&D investment on the export of the country where the R\&D investment took place. Belgium e.g. hosts some important R\&D subsidiaries of large MNEs. Barco is a Belgium firm with worldwide 700 R\&D employees of which $50 \%$ are localized in Belgium. Van de Velde has a similar structure. The company has different production units spread over the world but still prefers to do the main key activities such as design and product development, development and production of prototypes etc. at home. Alcatel-Lucent makes a clear distinction between its production and assembly sites and the sites hosting research and innovation. Belgium hosts one of these research and innovation sites, Bell labs, just as the USA, France, Germany, Ireland, India, China and South Korea. Production sites are also present in the USA, Europe, India and China, but additionally in other locations where no R\&D takes place such as Canada, Mexico and Brazil. In sum, Alcatel-Lucent tends to concentrate its R\&D in a limited amount of specialized sites of which one is located 
in Belgium. ${ }^{3}$ Therefore, the marginal increase in exports resulting from R\&D might be less pronounced for MNEs than for domestic firms.

\section{Data sources, variables and descriptive statistics}

For the analysis, data from the Flemish Community Innovation Survey (CIS) 2005 and 2007 are used. This survey is a European-wide, harmonized data collection on innovation according to the guidelines of the Oslo Manual (Eurostat/OECD, 2005). The data refer to the years 2004 and 2006. We have 1218 observations for 2006 and 913 for 2004. Since only $16 \%, 349$ firms, are observed in both years, we cannot use panel-econometric methods and apply pooled cross-sectional regressions. The firms in the sample cover the manufacturing sector, trade, transport, technical services and other business services. The CIS survey data is complemented with data from the BELFIRST database which contains balance sheet and income statement information. Furthermore, for the construction of the instrumental variables, data from the ICAROS database of IWT is used. ${ }^{4}$ The final sample consists of 2131 observations at the firm level.

\section{Dependent variable}

In the CIS survey, firms are requested to indicate the percentage of sales generated through export, that is, sales realized outside of Belgium. The dependent variable is thus defined as exports / total sales $* 100=$ export intensity (EXPINT).

\footnotetext{
${ }^{3}$ All figures mentioned in this paragraph were obtained from the companies' annual reports.

${ }^{4}$ IWT is the Flemish government agency administering the innovation policy schemes.
} 


\section{Explanatory variables}

To measure $R \& D$, scholars commonly use the $R \& D$ expenditures or $R \& D$ intensity ( $=\mathrm{R} \& \mathrm{D}$ expenditures / total sales) of a firm, which are flow variables (e.g. Hirsch and Bijaou, 1985; Ito and Pucik, 1993; Kirbach and Schmiedeberg, 2008 and Schlegelmilch and Crook, 1988). As R\&D expenditures in period $t$ will most likely not generate sales in period $t$ but in future periods, we prefer using a stock variable. The stock of $R \& D$ reflects the accumulated knowledge over time, and is thus a better proxy for the knowledge stock of the firm which serves as input factor for production. In the survey, firms are asked to indicate the amount of employees (physical units) engaged in internal $R \& D$ activities. We relate this $R \& D$ personnel to the total employment as stock variable measuring R\&D intensity of a firm (RNDEMP). As a robustness check we use the R\&D intensity (RNDINT) of a firm measured as the percentage of total amount of internal $R \& D$ expenditures over total sales as alternative proxy for the knowledge stock. It would certainly be an option to experiment with lags of $R \& D$ spending instead of using a stock or a contemporaneous relationship. However, our data does not contain enough time series information to explore this in more detail.

We use several other control variables. Following the literature on export and productivity we certainly want to control for this important variable even if it is not our main focus. We use labor productivity measured as added value per employee (PROD) (see e.g. Bernard and Jensen, 1999). The skill-level (SKILLS) is measured as the wage cost per employee (see e.g. Wakelin, 1998; Bleaney and Wakelin, 2002; Barrios et al., 2003, Ebling and Janz, 1999). The tangible assets per employee are used as an indicator for capital intensity (CAPINT) (see e.g. Wakelin, 1998; Bleaney 
and Wakelin, 2002). PROD, SKILLS and CAPINT are lagged with two years in order to avoid direct simultaneity with exports.

As a further control, we use firm size (SIZE) measured by the number of employees (see e.g. Wakelin, 1998; Bleaney and Wakelin, 2002; Hirsch and Bijaou, 1985; Barrios et al., 2003). ${ }^{5}$ AGE indicates the number of years the firm already exists. A YEAR dummy indicates whether an observation refers to 2004. To control for unobserved heterogeneity across sectors, 12 industry dummy variables are included. We also include a variable for multinationality (MNE) which indicates whether a firm is part of a multinational enterprise, that is, a Belgian parent of an MNE or Belgian subsidiary of a foreign parent company.

\section{Instrumental variables}

$\mathrm{R} \& \mathrm{D}$ personnel relative to total employment is a stock variable which might capture some R\&D effort of previous years. Still it is observed in the same time period as the export intensity and might therefore be endogenous to some extent. As stated above, we use R\&D subsidy information as instrumental variables. Two different measures are used. The ICAROS database provides detailed information about all subsidized R\&D projects in Flanders. As first instrument we use the number of subsidized R\&D projects for each firm in the sample. We count those subsidized projects that ended in the previous three years before the export and R\&D variables are observed. The second instrument measures the amount of subsidies received in all

\footnotetext{
${ }^{5}$ SIZE enters the regression in logarithmic form. We also tested for further non-linearity using
} $[\ln (\text { size })]^{2}$, but the squared term was always insignificant. 
of these projects. In order to avoid multicollinearity with the number of R\&D projects, we divide the total amount by the number of $\mathrm{R} \& \mathrm{D}$ projects that ended in the past three years, which gives the average size of subsidized projects.

\section{Descriptive statistics}

As already indicated, the total sample consists out of 2131 firms. $30 \%$ of them (646 firms) are part of an MNE. Descriptive statistics can be found in table 1.

Firms export on average $35 \%$ of their sales. For domestic firms, this figure is only $27 \%$ whereas it amounts to $53 \%$ for MNEs. The average internal R\&D expenditures for the full sample is 369410 EUR, 1095256 EUR for the MNEs and 117530 EUR for the domestic firms. The average R\&D intensity amounts to $1.61 \%$ for domestic firms and $2.06 \%$ for MNEs. The full sample has an average R\&D intensity of $1.75 \%$. Firms have on average 4.51 R\&D employees. Domestic firms have on average 2.18 R\&D employees while this average amounts to 9.88 for MNEs. The average R\&D personnel over total employment is for both subsamples approximately $5 \%$. As one can observe, export, $R \& D$ personnel, $R \& D$ and $R \& D$ intensity are on average larger for MNEs than for domestic firms. MNEs are on average also larger, more productive, more capital intensive, older and employ a higher share of skilled labor than domestic firms. 
Table 1: Descriptive statistics (2131 observations)

\begin{tabular}{lcccccccccccc} 
& \multicolumn{1}{l}{$\begin{array}{l}\text { Full Sample } \\
\text { ( observations 2131) }\end{array}$} & & \multicolumn{3}{c}{$\begin{array}{l}\text { Domestic Owned firms } \\
(1485 \text { observations })\end{array}$} & \multicolumn{4}{c}{$\begin{array}{l}\text { MNEs } \\
\text { (646 observations) }\end{array}$} \\
\hline & Mean & Std. Dev. & Min. & Max. & Mean & Std. Dev. & Min. & Max. & Mean & Std. Dev. & Min. & Max. \\
\hline EXPINT & 34.58 & 36.41 & 0 & 100 & 26.50 & 32.13 & 0 & 100 & 53.16 & 38.80 & 0 & 100 \\
EXPVOL & 20041 & 89482 & 0 & 2047704 & 6738 & 36309 & 0 & 1095256 & 50620 & 148543 & 0 & 2047704 \\
RND PERSONEL & 4.51 & 20.55 & 0 & 428 & 2.18 & 11.74 & 0 & 380 & 9.88 & 32.19 & 0 & 428.00 \\
RNDEMP & 0.05 & 0.11 & 0 & 0.76 & 0.05 & 0.11 & 0 & 0.76 & 0.05 & 0.10 & 0 & 0.75 \\
RND & 369.41 & 1968.73 & 0 & 40959 & 117.53 & 727.59 & 0 & 19470 & 948.42 & 33331.62 & 0 & 40959 \\
RNDINT & 1.75 & 6.09 & 0 & 76.53 & 1.61 & 6.25 & 0 & 76.53 & 2.06 & 5.69 & 0 & 61.62 \\
SIZE & 107.16 & 205.14 & 1 & 1994 & 59.62 & 109.47 & 1 & 1587 & 216.42 & 306.99 & 4 & 1994 \\
AGE & 31. AA & 25.63 & 2 & 227 & 30.11 & 25.24 & 2 & 227 & 33.41 & 26.36 & 1 & 176 \\
PROD & 67.82 & 46.74 & 8.90 & 1017.05 & 59.43 & 34.40 & 8.90 & 489.39 & 87.12 & 62.89 & 9.66 & 1017.05 \\
SKILLS & 42.73 & 16.67 & 5 & 129.28 & 38.25 & 12.87 & 5 & 125.07 & 53.04 & 19.59 & 9.21 & 129.28 \\
CAPINT & 39.21 & 84.27 & 0.78 & 704.83 & 34.95 & 53.93 & 0.68 & 1377.95 & 49.01 & 128.92 & 0.76 & 2368.91 \\
Number of subsidized projects & 0.19 & 0.75 & 0 & 14 & 0.15 & 0.50 & 0 & 5 & 0.29 & 1.12 & 0 & 14 \\
Average size of subsidized projects & 15.08 & 80.04 & 0 & 1505.90 & 6.67 & 32.24 & 0 & 604.44 & 34.43 & 135.01 & 0 & 1505.90 \\
\hline
\end{tabular}

Note: 12 industry dummies are not presented.

\section{Estimation results}

Standard microeconometric techniques are employed for the multivariate analysis. First, we perform a Tobit regression for export intensity, treating $R \& D$ as exogenous. As the Tobit model requires the assumption of normality, we prefer to use the log of our dependent variable to reduce the skewness of the distribution. Not all firms export, so some observations have the value of zero. As we cannot take the log of zero, we impute the smallest, observed positive value for these censored observations. This just implies that we treat the observation with the smallest export value as censored. The bias arising from this transformation should be minimal.

Results of the Tobit regression for the full sample can be found in table 2, column [1]. R\&D personnel relative to total employment has a positive significant effect on export intensity. As Tobit models are non-linear we calculate the marginal effect as the change in the expect value of export intensity as response to a change in $R \& D$ employment intensity, that is, $\partial \mathrm{E}(\mathrm{Y} \mid \mathrm{X}) / \partial \mathrm{x}_{\mathrm{k}}=\Phi\left(\mathrm{x}_{\mathrm{i}}{ }^{\prime} \beta / \sigma\right) \beta$ (see e.g. Verbeek, 2000, for more technical details). The marginal effect of $R \& D$ on export is 7.90 in this case. In terms of economic magnitude, one should interpret this effect with a certain care. 
Usually one considers a one unit change in the explanatory variable. As the regressor is a share, however, this makes little sense in this setting. The sample average of RDEMP is 0.05 , that is, a firm would employ 5 out of 100 people in $R \& D$. What is a reasonable change to be considered? Let us refer to the subsidy example. Suppose the "average firm" would receive a large subsidy. This could mean, for instance, that it hires three new $R \& D$ employees. In this case, the regressor would take the value 8/103 resulting in a change of 0.028 approximately. As our dependent variable is measured in logarithmic form, a change in a regressor reflects a growth rate in the dependent variable. The effect would amount to $22 \%(=7.9 * 0.028)$. As the average firm shows an export share of $34.6 \%$, the estimated increase would lead to an export intensity of about $42.2 \%[=34.6+(34.6 * 0.22)]$.

The results concerning the other controls variables are in line with previous literature. Productivity has a positive significant effect on export (e.g. Arnold and Hussinger, 2005). Additionally, the size, age and capital intensity of the firm is a significant determinant of export intensity. Finally, the dummy variable, indicating if the firm is part of an MNE is significant indicating that firms that are part of an MNE have a higher export intensity, all else constant.

As indicated, we perform the analysis on the subsample of MNEs and domestic firms and results can be found in columns [2] and [3] of table 2. Results indicate that RNDEMP is of significant importance for export for domestic firms and MNEs. The marginal effect for domestic firms is 8.07 and slightly bigger than the marginal effect for MNEs which has a value of 6.93. However, when testing if this difference is significantly different from zero, the null hypothesis is not rejected. For reasons of brevity, we do not discuss the results concerning the other control variables in detail. 
Table 2: Tobit estimations

\begin{tabular}{|c|c|c|c|}
\hline & TOBIT & TOBIT domestic firms & TOBIT MNEs \\
\hline & \multicolumn{3}{|c|}{ Dependent variable: } \\
\hline & Log(EXPINT) & $\log ($ EXPINT $)$ & $\log ($ EXPINT) \\
\hline & [1] & [2] & {$[3]$} \\
\hline \multirow[t]{2}{*}{ Variable: } & Coefficient & Coefficient & Coefficient \\
\hline & (Std. err.) & (Std. err.) & (Std. err.) \\
\hline \multirow[t]{2}{*}{$\overline{\text { RNDEMP }}$} & $8.892 * * *$ & $9.761 * * *$ & $7.070 * * *$ \\
\hline & $(0.969)$ & $(1.265)$ & $(1.440)$ \\
\hline \multirow[t]{2}{*}{$\log (\mathrm{SIZE})$} & $0.440 * * *$ & $0.644 * * *$ & 0.108 \\
\hline & $(0.091)$ & $(0.130)$ & $(0.117)$ \\
\hline \multirow[t]{2}{*}{$\log (\mathrm{AGE})$} & $0.343 * *$ & 0.246 & $0.502 * * *$ \\
\hline & $(0.139)$ & $(0.188)$ & $(0.188)$ \\
\hline \multirow[t]{2}{*}{ PROD } & $0.009 * * *$ & $0.012 * * *$ & $0.006^{*}$ \\
\hline & $(0.003)$ & $(0.005)$ & $(0.003)$ \\
\hline \multirow[t]{2}{*}{ SKILLS } & $0.024 * * *$ & $0.040 * * *$ & 0.003 \\
\hline & $(0.008)$ & $(0.013)$ & $(0.009)$ \\
\hline \multirow[t]{2}{*}{ CAPINT } & $-0.005 * * *$ & $-0.005^{*}$ & $-0.003 * *$ \\
\hline & $(0.001)$ & $(0.003)$ & $(0.001)$ \\
\hline \multirow[t]{2}{*}{ YEAR } & 0.100 & 0.006 & 0.311 \\
\hline & $(0.194)$ & $(0.258)$ & $(0.275)$ \\
\hline \multirow[t]{2}{*}{ MNE } & $1.190 * * *$ & & \\
\hline & $(0.249)$ & & \\
\hline F-Test on joint sign. of ind. dummies & $\mathrm{F}(11,1664)=18.85 * * *$ & $\mathrm{~F}(11,1467)=14.83^{* * *}$ & $\mathrm{~F}(11,628)=6.44 * * *$ \\
\hline$\overline{\text { Log Likelihood }}$ & -5080.46 & -3460.84 & -1566.74 \\
\hline McFadden $R^{2}$ & 0.045 & 0.040 & 0.039 \\
\hline Number of observations & 2131 & 1485 & 646 \\
\hline
\end{tabular}

Notes: Standard errors in parentheses, $* * *(* *, *)$ indicate a significance level of $1 \%(5 \%, 10 \%)$. All models include an intercept not reported here.

Before instrumenting $R \& D$, we test whether this variable is endogenous using the Smith-and Blundell (1986) test. The procedure is as follows:

(1) We run a regression of the ratio of $R \& D$ employees over total employees on all exogenous variables and our instrumental variables, and obtain the residuals from this regression.

(2) We estimate the Tobit model as above, but now also include the residuals obtained in step 1.

(3) The standard t-statistic of the coefficient of the included residuals is a valid test on endogeneity of the $\mathrm{R} \& \mathrm{D}$ employment over total employment variable. 
In order to run an IV regression convincingly the instrumental variables must be relevant, that is, they should show a high partial correlation with the potentially endogenous regressor. Results from the first stage OLS regression can be found in table 3 in the appendix. Results for the full sample in column [4] indicate that there is a partial F-value of the instrumental variables of 31.95. According to Staiger and Stock (1997) a partial F-value of the instrumental variable in the first stage regression should exceed the value of 10 . Therefore we can conclude that the instruments are relevant, and thus the IV regressions will not suffer from a possible weak instrument bias.

\section{Table 3: First stage OLS results}

\begin{tabular}{|c|c|c|c|}
\hline & OLS & OLS domestic firms & OLS MNEs \\
\hline & \multicolumn{3}{|c|}{ Dependent variable: } \\
\hline & RNDEMP & RNDEMP & RNDEMP \\
\hline & {$[4]$} & {$[5]$} & {$[6]$} \\
\hline \multirow[t]{2}{*}{ Variable: } & Coefficient & Coefficient & Coefficient \\
\hline & (Std. err.) & (Std. err.) & (Std. err.) \\
\hline \multirow[t]{2}{*}{$\overline{\log (\text { SIZE })}$} & $-0.014 * * *$ & $-0.014 * * *$ & $-0.016 * * *$ \\
\hline & $(0.002)$ & $(0.003)$ & $(0.003)$ \\
\hline \multirow[t]{2}{*}{$\log (\mathrm{AGE})$} & $-0.006 * *$ & -0.004 & $-0.013 *$ \\
\hline & $(0.003)$ & $(0.003)$ & $(0.005)$ \\
\hline \multirow[t]{2}{*}{ PROD / 100} & 0.008 & 0.010 & 0.008 \\
\hline & $(0.007)$ & $(0.010)$ & $(0.009)$ \\
\hline \multirow[t]{2}{*}{ SKILLS / 100} & 0.028 & 0.045 & 0.015 \\
\hline & $(0.023)$ & $(0.034)$ & $(0.025)$ \\
\hline \multirow[t]{2}{*}{ CAPINT / 100} & -0.002 & 0.005 & $-0.005^{*}$ \\
\hline & $(0.002)$ & $(0.004)$ & $(0.003)$ \\
\hline \multirow[t]{2}{*}{ YEAR } & -0.001 & -0.004 & $0.012 *$ \\
\hline & $(0.004)$ & $(0.005)$ & $(0.007)$ \\
\hline \multirow[t]{2}{*}{ MNE } & 0.006 & & \\
\hline & $(0.006)$ & & \\
\hline \multirow[t]{2}{*}{ Number of subsidized projects } & $0.029 * * *$ & $0.035 * * *$ & $0.023 * * *$ \\
\hline & $(0.006)$ & $(0.008)$ & $(0.008)$ \\
\hline \multirow[t]{2}{*}{ Average size of subsidized projects } & $0.136 * * *$ & $0.299 *$ & $0.132 * * *$ \\
\hline & $(0.045)$ & $(0.156)$ & $(0.050)$ \\
\hline F-Test on joint sign. of ind. dummies & $\mathrm{F}(11,2110)=11.35^{* *}$ & $\mathrm{~F}(11,1465)=6.52 * * *$ & $\mathrm{~F}(11,626)=6.31 * * *$ \\
\hline F-Test on joint sign. of IV & $\mathrm{F}(2,2110)=31.95 * * *$ & $\mathrm{~F}(2,1465)=21.71 * * *$ & $\mathrm{~F}(2,626)=20.25 * * *$ \\
\hline$\overline{R^{2}}$ & 0.222 & 0.197 & 0.330 \\
\hline Number of observations & 2131 & 1485 & 646 \\
\hline
\end{tabular}


These regressions also indicate that $R \& D$ policy increases $R \& D$ in subsidized firms, as both the number of subsidized $R \& D$ projects and the average size of subsidized projects are positively significant in the first-stage regression.

When conducting the Smith-Blundell test, we find that the exogeneity of R\&D is clearly rejected for the full sample and for the subsample of domestic firms. Therefore, we have to apply IV Tobits. Note that exogeneity is not rejected in the MNE sample. However, we show the results of the IV regressions for comparison.

A necessary condition for obtaining consistent estimates in IV models is also the validity of instruments, that is, they must be exogenous. To test this, an overidentification test is performed. The Amemiya-Lee-Newey minimum chi-square statistic (Amemiya, 1978; Newey, 1987; Lee 1992), displayed in table 4, indicates a value of 0.995 and a p-value of 0.3184 which means that the null hypothesis of exogenous instruments is not rejected. ${ }^{6}$

Results of the IV Tobit estimation for the full sample can be found in column [7] of table 4 . The ratio of $R \& D$ employees over total employees has a significant influence on export intensity. The marginal effect for the full sample is 14.65 . Here again we find a confirmation for the positive effect of productivity on export. Also size, age, capital intensity, skills and MNE have a significant influence on export

\footnotetext{
${ }^{6}$ This statistical finding also confirms our expectations from personal communications with IWT agents. Although we already use lagged values of $R \& D$ subsidy variables to avoid feedback from exports to our instruments for $\mathrm{R} \& \mathrm{D}$, we were told that the subsidy grant decision is based on expert peer reviews of the submitted proposals and that firm characteristics such as export behavior do not enter the decision process at IWT. The overidentification test thus reaffirms our specification.
} 
intensity. As before, we also perform the analysis on the subsamples; column [8] and [9] of table 4. Also here the results remain robust. The marginal effect of R\&D employees over total employees for the MNEs is 8.47 . For the domestic firms, the importance of $R \& D$ intensity is significant, the marginal effect amounts to 25.89 . This indicates that $R \& D$ has a significant effect on export intensity for domestic firms and for MNE. A test on significant differences across the two samples shows that the null hypothesis is rejected at the $5 \%$ level in this case ( $\mathrm{p}$-value $=0.02)$. Consequently, R\&D has a larger effect on exports in domestic firms than in MNEs as we expected.

Table 4: IV Tobit estimations

\begin{tabular}{|c|c|c|c|}
\hline & IVTOBIT & IVTOBIT domestic firms & IVTOBIT MNES \\
\hline & \multicolumn{3}{|c|}{ Dependent variable: } \\
\hline & $\log ($ EXPINT $)$ & $\log ($ EXPINT $)$ & $\log ($ EXPINT $)$ \\
\hline & [7] & {$[8]$} & [9] \\
\hline Variable: & $\begin{array}{l}\text { Coefficient } \\
\text { (Std. err.) }\end{array}$ & Coefficient & Coefficient \\
\hline \multirow{2}{*}{ RNDEMP } & $16.552 * * *$ & $32.281 * * *$ & $8.636 * *$ \\
\hline & $(3.334)$ & $(5.687)$ & $(3.669)$ \\
\hline \multirow[t]{2}{*}{$\log ($ SIZE $)$} & $0.521 * * *$ & $0.943 * * *$ & 0.121 \\
\hline & $(0.098)$ & $(0.161)$ & $(0.120)$ \\
\hline \multirow[t]{2}{*}{$\log (\mathrm{AGE})$} & $0.404 * * *$ & 0.321 & $0.531 * * *$ \\
\hline & $(0.143)$ & $(0.208)$ & $(0.198)$ \\
\hline \multirow[t]{2}{*}{ PROD } & $0.008 * * *$ & $0.011 * *$ & 0.005 \\
\hline & $(0.003)$ & $(0.005)$ & $(0.104)$ \\
\hline \multirow[t]{2}{*}{ SKILLS } & $0.021 * * *$ & $0.028 *$ & 0.003 \\
\hline & $(0.008)$ & $(0.014)$ & $(0.009)$ \\
\hline \multirow[t]{2}{*}{ CAPINT } & $-0.005^{* * *}$ & $-0.006^{*}$ & $-0.003 *$ \\
\hline & $(0.001)$ & $(0.003)$ & $(0.001)$ \\
\hline \multirow[t]{2}{*}{ YEAR } & 0.105 & 0.158 & 0.289 \\
\hline & $(0.197)$ & $(0.286)$ & $(0.279)$ \\
\hline \multirow[t]{2}{*}{ MNE } & $1.124 * * *$ & & \\
\hline & $(0.254)$ & & \\
\hline F-Test on joint sign. of ind. dummies & $\mathrm{F}(11)=207.19 * * *$ & $\mathrm{~F}(11)=151.14 * * *$ & $\mathrm{~F}(11)=68.56^{* * *}$ \\
\hline Amemiya-Lee-Newey min. chi-sq statistic & $\chi 2(1)=0.995$ & $\chi 2(1)=0.139$ & $\chi 2(1)=0.007$ \\
\hline Number of obs. & 2131 & 1485 & 646 \\
\hline
\end{tabular}

Notes: Standard errors in parentheses, $* * *(* *, *)$ indicate a significance level of $1 \%(5 \%$, $10 \%)$. All models include an intercept not reported here.

\section{Robustness test I: OLS estimations}

We also test if the positive effect of $R \& D$ on export remains robust when using OLS estimations. On the one hand, the Tobit models are the preferred estimations, as 
they account for the left-censoring of the variable. However, these estimations rely on the restrictive assumption of normality. OLS, on the other hand, does not account for censoring but does not rely on the normality assumption. In the most extreme case of no censoring and a valid normality assumption, Tobit would coincide with OLS. In our case, we would expect that OLS underestimates the slope coefficients to some extent in the full sample and in the case of domestic firms. However, in the sample of MNEs the censoring of the dependent variable is basically negligible which makes OLS a decent robustness test to Tobit without imposing normality.

We use the same variables as indicated before. Results of the OLS analysis are displayed in table 5 in the appendix. Column [10] of table 5 indicates that R\&D employees over total employees have a positive influence on export intensity. Subsample results for domestic firms and MNEs in column [11] and [12] respectively are similar to the results for the Tobit estimation. Table 6 presents Two-Stage Least Squares regressions where we instrument $R \& D$ as we did in the Tobit case. We also test for the validity of the instruments using the Hansen $J$ statistic. As in the Tobit case, the validity of instruments is not rejected. As Table 6 indicates, all results reported previously hold also in the linear regression model.

\section{Robustness test II: using R\&D intensity}

As an additional robustness test, we use the $R \& D$ intensity measured as $R \& D$ expenditure divided by total sales as a proxy for the R\&D efforts of the firm.

The results of the Tobit analysis indicate that $R \& D$ expenditures have a positive influence on export intensity. The subsample results for domestic firms and MNEs are similar to the results for the ratio R\&D employees over total employees. Tests for 
endogeneity reveal an endogeneity problem for the full sample and for the subsample of domestic firms. Therefore we perform an IV Tobit analysis. Again the positive significant effect of $R \& D$ measured as $R \& D$ intensity on export is confirmed. As all previous results are also confirmed with this different R\&D measure, we refrain from presenting the results in more detail.

\section{Robustness test III: using a specification in levels of export and $R \& D$}

So far, all models have been specified in terms of intensities, that is, exports divided by total sales and $\mathrm{R} \& \mathrm{D}$ employment or expenditure divided by total employment or total sales, respectively. As final robustness check, we re-estimated our models using a specification in $(\log )$ levels of total export volume and R\&D. As the results were similar to the ones reported before, we do not present them in more detail.

\section{Conclusion}

For small open economies, export is an important factor for growth and welfare. Since $R \& D$ and innovation are key factors of growth for an industralized economy, it is interesting to analyze the relationship between $\mathrm{R} \& \mathrm{D}$ and export for Belgium as one example of a small, open and industrialized economy. The econometric analysis based on Belgium firm level data confirms that $R \& D$ is an important driver of export activities.

In addition, we show that policies targeted towards $R \& D$ may indirectly help to increase the export performance of the economy. These results hold if potential feedback effects of export on R\&D are taken into account by IV regressions. 
When looking at Belgium, we also observe a high presence of MNEs relative to domestic firms. Due to e.g. intra-firm transport and concentrated localization of R\&D activities across borders this may influence the export intensity as well as R\&D efforts of these firms, and consequently the effect of $R \& D$ on exports. Therefore we compare the effects in a split sample of domestic firms and MNEs. It turns out that $R \& D$ has a positive effect in both samples. However, the marginal effect is larger for domestic companies than for MNEs once we account for possible endogeneity of R\&D in the regressions.

Our results are of interest for policy: first, we find that R\&D policy can be seen as an indirect stimulus for export in small, open economies. Second, we find this effect for both domestic firms and MNEs. This is reassuring for policy makers that have the concern that $R \& D$ subsidies may lead to more $R \& D$ in the economy, but in case of MNEs to no further benefits as production may take place elsewhere. Even in the case of MNEs we are able to measure an export stimulus. However, it is smaller for MNEs than for domestic companies.

For further research it would be interesting to investigate another mechanism that may be stimulated through R\&D. Belgium hosts many subsidiaries of foreign parent companies. Targeted R\&D subsidies may not only trigger exports of firms, but also make Belgian subsidiaries more attractive compared to subsidiaries in other countries, all else constant. Therefore, it would be worthwile to investigate the effect of R\&D subsidies and possibly also other local location factors on FDI inflows of parent companies, as subsidiaries generally compete for capital input from parent companies. In the ideal case, one could reach a conclusion on benchmarking the benefits of subsidizing domestic companies versus MNEs. On the one hand, funding domestic 
firms may ensure that not only R\&D but also production remains in the home country. However, subsidizing MNEs may results in similar effects but may also attract more foreign capital which may outweigh the concern of foreign production of domestically produced $R \& D$ result in an open knowledge economy.

Finally, it would be interesting to compare the effect of R\&D subsidies and direct export subsidies. It may be the case that $\mathrm{R} \& \mathrm{D}$ subsidies create a more sustainable advantage than export subsidies that are targeted at entering foreign markets with given products or technologies.

\section{References}

Almus, M., \& Czarnitzki, D. (2003). The Effects of Public R\&D Subsidies on Firms' Innovation Activities: The Case of Eastern Germany. Journal of Business and Economic Statistics, 21(2), 226-236.

Amemiya, T. (1978). The estimation of a simultaneous equation generalized probit model. Econometrica, 46(5), 1193-1205.

Arnold, J.M., \& Hussinger, K. (2005). Export behavior and firm productivity in German manufacturing: a firm-level analysis. Review of World Economics, 141(2), 219-243.

Barrios, S., Görg, H., \& Strobl, E. (2003). Explaining firms’ export behaviour: R\&D, Spillovers and the destination market. Oxford Bulletin of Economics and Statistics, 65(4), 475-495.

Becker, S.O., \& Egger, E. (2009). Endogenous product versus process innovation and a firm's propensity to export. Empirical Economics, forthcoming. 
Belderbos, R., Duvivier, F. \& Wynen, J. (2009). Innovation and export competitiveness: Evidence from Flemish firms. Working paper STOIO, 2009/3, Leuven.

Bellak, C. (2004). How domestic and foreign firms differ and why does it matter? Journal of Economic Surveys, 18 (4), 483-514.

Bernard, A.B., \& Jensen, J.B. (1999). Exceptional exporter performance: cause, effect or both? Journal of International Economics, 47(1), 1-25.

Bleaney, M., \& Wakelin K. (2002). Efficiency, innovation and exports. Oxford Bulletin of Economics and Statistics, 64(3), 3-15.

Cassidy, M., Görg, H., \& Strobl, E. (2005). Knowledge accumulation, and productivity: Evidence from plant-level data for Ireland. Scottish Journal of Political Economy, 52(3), 344-358.

Cassiman, B., \& Golovko, E. (2007). Innovation and the export-productivity link. CEPR Discussion Papers No. 6411, London.

Cassiman, B., \& Golovko, E. (2010). Innovation and internationalization through exports. Journal of International Business Studies, forthcoming.

Cassiman, B., Golovko, E., \& Martinez-Ros, E. (2010). Innovation, exports and productivity. International Journal of Industrial Organization, 28(4), 372-376.

Castellani, D., \& Zanfei, A. (2007). Internationalization, Innovation and Productivity: How do firms differ in Italy? The World Economy, 30(1), 156-176. 
Cerulli, G. (2010). Modelling and measuring the effect of public subsidies on business R\&D: a critical review of the economic literature. Economic Record, 86(274), 421-449.

Criscuolo, C., \& Martin, R. (2009). Multinationals and US productivity leadership: Evidence from Great Britain. The Review of Economics and Statistics, 91(2), 263281.

Czarnitzki, D., Ebersberger, B., \& Fier, A. (2007). The relationship between R\&D collaboration, subsidies and R\&D performance: empirical evidence from Finland and Germany. Journal of Applied Econometrics, 22(7), 1347-1366.

David, P.A., Hall, B.H., \& Toole, A. A. (2000). Is public R\&D a complement or substitute for private R\&D? A review of the econometric evidence. Research Policy, 29(4-5), 497-529.

De Backer, K., \& Sleuwaegen, L. (2003). Foreign ownership and productivity dynamics. Econonomic Letters, 79(2), 177-183.

Dollar, D. (1986). Technological innovation, capital mobility, and the product cycle in Nort-South trade. The American Economic Review, 76(1), 177-190.

Doms, M.E., \& Jensen, J.B. (1998). Comparing wages, skills, and productivity between domestically and foreign-owned manufacturing establishments in the United States, in: R.E. Baldwin and R.E. Lipsey and J.D. Richards (eds.), Geography and Ownership as Bases for Economic Accounting, Chicago: University of Chicago Press. 
Ebling, G., \& Janz, N. (1999). Eport and innovation activities in the German service sector: empirical evidence at the firm level. ZEW Discussion Paper, 99-53, Mannheim.

Eurostat \& OECD (2005), Oslo-Manual - Proposed guidelines for collecting and interpreting technological innovation data, $3^{\text {rd }}$ ed., Paris.

Frenz, M., Girardone, C. \& Ietto-Gillies, G. (2005). Multinationality matters in innovation: The case of the UK financial services. Industry and Innovation, 12(1), $65-92$.

Gerfin, M., \& Lechner, M. (2002). A microeconometric evaluation of the active labour market policy in Switzerland. The Economic Journal, 112 (482), 854-893.

Girma, S., Görg, H., \& Hanley, A. (2008). R\&D and Exporting: A comparison of British and Irish firms. Review of World Economics, 144(4), 750-773.

Griliches, Z. (1994). Productivity, R\&D and data constraints. American Economic Review, 48(1), 1-21.

Grossman, G.M., \& Helpman, E. (1989). Product development and international trade. Journal of Political Economy, 97(6), 1261-1283.

Hall, B.H., \& Mairesse, J. (1995). Exploring the relationship between R\&D and productivity in French manufacturing firms. Journal of Econometrics, 65(1), 263293.

Hirsch, S., \& Bijaoui, I. (1985). R\&D intensity and export performance: A micro view. Review of World Economics, 121(2), 230-251. 
Hussinger, K. (2008). R\&D and subsidies at the firm level: an application of parametric and semiparametric two-step selection model. Journal of Applied Econometrics, 23(6), 729-747.

Ito, K., \& Pucik, V. (1993). R\&D spending, domestic competition and export performance of Japanese manufacturing firms. Strategic Management Journal, 14(1), 61-75.

Kirbach, M., \& Schmiedeberg, C. (2008). Innovation and export performance: adjustment and remaining differences in East and West German manufacturing. Economics of Innovation and New Technology, 17(5), 435-457.

Krugman, P. (1979). A model of innovation, technology transfer, and the world distribution of income. Journal of Political Economy, 87(2), 253-267.

Lachenmaier, S., \& Wössmann, L. (2006). Does innovation cause exports? Evidence from exogenous innovation impulses and obstacles using German micro data. Oxford Economic papers, 58(2), 317-350.

Lee, L. (1992). Amemiya's Generalized Least Squares and tests of overidenfication in simultaneous equation models with qualitative or limited dependent variables. Econometric Reviews, 11(3), 319-328.

Newey, W.K. (1987). Efficient Estimation of Limited Dependent Variable Models with Endogeneous Explanatory Variables. Journal of Econometrics, 36(3), 231250.

OECD (2009). Main Science and Technology Indicators, Paris 
Peters, B. (2009). Persistence of Innovation: Stylised Facts and Panel Data Evidence. Journal of Technology Transfer, 34(2), 226-243.

Roper, S., \& Love, J.H. (2002). Innovation and export performance: evidence from the UK and German manufacturing plants. Research Policy, 31(7), 1087-1102.

Schlegelmilch, B.B., \& Crook, J.N. (1988). Firm-level determinants of export intensity. Managerial and Decision Economics, 9(4), 291-300.

Smith, R., \& Blundell, R. (1986). An exogeneity test for a simultaneous equation Tobit model with an application to labor supply. Econometrica, 54(3), 679-685.

Staiger, D., \& Stock, J. (1997). Instrumental variables regression with weak instruments. Econometrica, 65(3), 557-586.

UNCTAD (2009). World Investment Report 2009. New York and Geneva.

Van Beveren, I., \& Vandenbussche, H. (2010). Product and process innovation and the decision to export. Journal of Economic Policy, 13(1), 3-24.

Verbeek, M. (2000). A guide to modern econometrics: Chichester: Wiley.

Vernon, R. (1966). International Investment and International Trade in the Product Cycle. The Quarterly Journal of Economics, 80 (2), 190-207.

Wakelin, K. (1998). Innovation and export behaviour at the firm level. Research Policy, 26(7-8), 829-841.

Wagner, J. (2007). Exports and Productivity: A survey of the evidence from firm level data. The World Economy, 30(1), 60-82.

Young, A. (1991). Learning by doing and the dynamic effects of international trade. Quarterly Journal of Economics, 106(2), 369-405. 


\section{Appendix}

Table 5: OLS estimations

\begin{tabular}{|c|c|c|c|}
\hline & OLS & OLS domestic firms & OLS MNEs \\
\hline & $\begin{array}{c}\log (\text { EXPINT }) \\
{[10]}\end{array}$ & $\begin{array}{c}\text { Dependent variable: } \\
\log (\text { EXPINT }) \\
{[11]}\end{array}$ & $\begin{array}{c}\log (\text { EXPINT }) \\
{[12]}\end{array}$ \\
\hline Variable: & $\begin{array}{l}\text { Coefficient } \\
\text { (Std. err.) }\end{array}$ & $\begin{array}{l}\text { Coefficient } \\
\text { (Std. err.) }\end{array}$ & $\begin{array}{c}\text { Coefficient } \\
\text { (Std. err.) }\end{array}$ \\
\hline RNDEMP & $\begin{array}{c}6.916 * * * \\
(0.832)\end{array}$ & $\begin{array}{c}7.152 * * * \\
(1.111)\end{array}$ & $\begin{array}{c}6.172 * * * \\
(1.021)\end{array}$ \\
\hline $\log ($ SIZE) & $\begin{array}{c}0.370 * * * \\
(0.068)\end{array}$ & $\begin{array}{c}0.525 * * * \\
(0.088)\end{array}$ & $\begin{array}{c}0.094 \\
(0.104)\end{array}$ \\
\hline $\log (\mathrm{AGE})$ & $\begin{array}{c}0.251 * * \\
(0.100)\end{array}$ & $\begin{array}{c}0.157 \\
(0.125)\end{array}$ & $\begin{array}{c}0.424 * * * \\
(0.159)\end{array}$ \\
\hline PROD & $\begin{array}{c}0.007 * * * \\
(0.002)\end{array}$ & $\begin{array}{c}0.010 * * \\
(0.004)\end{array}$ & $\begin{array}{l}0.005^{*} \\
(0.003)\end{array}$ \\
\hline SKILLS & $\begin{array}{c}0.017 * * * \\
(0.006)\end{array}$ & $\begin{array}{c}0.025 * * \\
(0.010)\end{array}$ & $\begin{array}{c}0.003 \\
(0.008)\end{array}$ \\
\hline CAPINT & $\begin{array}{l}-0.003 \\
(0.002)\end{array}$ & $\begin{array}{l}-0.003 \\
(0.001)\end{array}$ & $\begin{array}{c}-0.002^{*} \\
(0.001)\end{array}$ \\
\hline YEAR & $\begin{array}{c}0.089 \\
(0.143)\end{array}$ & $\begin{array}{c}0.015 \\
(0.179)\end{array}$ & $\begin{array}{c}0.273 \\
(0.232)\end{array}$ \\
\hline MNE & $\begin{array}{c}0.972 * * * \\
(0.183)\end{array}$ & & \\
\hline F-Test on joint sign. of ind. dummies & $\mathrm{F}(11,2111)=12.45 * * *$ & $\mathrm{~F}(11,1466)=16.97 * * *$ & $\mathrm{~F}(11,627)=7.91 * * *$ \\
\hline$\overline{R^{2}}$ & 0.218 & 0.190 & 0.188 \\
\hline Number of observations & 2131 & 1485 & 646 \\
\hline
\end{tabular}




\section{Table 6: Linear IV regressions}

\begin{tabular}{|c|c|c|c|}
\hline & IVREG & IVREG domestic firms & IVREG MNEs \\
\hline & \multicolumn{3}{|c|}{ Dependent variable: } \\
\hline & $\log ($ EXPINT $)$ & $\log ($ EXPINT $)$ & $\log ($ EXPINT $)$ \\
\hline & [13] & [14] & [15] \\
\hline Variable: & $\begin{array}{l}\text { Coefficient } \\
\text { (Std. err.) }\end{array}$ & $\begin{array}{c}\text { Coefficient } \\
\text { (Std. err.) }\end{array}$ & $\begin{array}{c}\text { Coefficient } \\
\text { (Std. err.) }\end{array}$ \\
\hline$\overline{\text { RNDEMP }}$ & $\begin{array}{c}13.412 * * * \\
(2.055)\end{array}$ & $\begin{array}{c}24.629 * * * \\
(3.527)\end{array}$ & $\begin{array}{c}7.789 * * * \\
(2.061)\end{array}$ \\
\hline $\log ($ SIZE $)$ & $\begin{array}{c}0.440 * * * \\
(0.069)\end{array}$ & $\begin{array}{c}0.760 * * * \\
(0.108)\end{array}$ & $\begin{array}{c}0.108 \\
(0.096)\end{array}$ \\
\hline $\log (\mathrm{AGE})$ & $\begin{array}{c}0.302 * * * \\
(0.102)\end{array}$ & $\begin{array}{c}0.217 \\
(0.136)\end{array}$ & $\begin{array}{c}0.453 * * * \\
(0.161)\end{array}$ \\
\hline PROD & $\begin{array}{c}0.007 * * * \\
(0.002)\end{array}$ & $\begin{array}{c}0.008 * * \\
(0.004)\end{array}$ & $\begin{array}{l}0.004 * \\
(0.003)\end{array}$ \\
\hline SKILLS & $\begin{array}{c}0.015 * * \\
(0.007)\end{array}$ & $\begin{array}{c}0.015 \\
(0.013)\end{array}$ & $\begin{array}{c}0.003 \\
(0.008)\end{array}$ \\
\hline CAPINT & $\begin{array}{c}-0.003 * * * \\
(0.001)\end{array}$ & $\begin{array}{c}-0.004 * * * * \\
(0.001)\end{array}$ & $\begin{array}{c}-0.002 * \\
(0.001)\end{array}$ \\
\hline YEAR & $\begin{array}{c}0.093 \\
(0.145)\end{array}$ & $\begin{array}{c}0.132 \\
(0.203)\end{array}$ & $\begin{array}{c}0.250 \\
(0.232)\end{array}$ \\
\hline MNE & $\begin{array}{c}0.916^{* * * *} \\
(0.188)\end{array}$ & & \\
\hline F-Test on joint sign. of ind. dummies & $\mathrm{F}(11)=234.45 * * *$ & $\mathrm{~F}(11)=104.62 * * *$ & $\mathrm{~F}(11)=88.70^{* * *}$ \\
\hline Hansen $J$-statistic & $\chi 2(1)=1.200$ & $\chi 2(1)=0.115$ & $\chi^{2(1)}=0.013$ \\
\hline Number of obs. & 2131 & 1485 & 646 \\
\hline
\end{tabular}

